\title{
Review on Insurance and their Present Status in Nepalese Economy
}

\author{
Nirdosh Khanal
}

\begin{abstract}
The study aims to overview the types of insurance operating in Nepal, product delivered by them and status of insurance market in Nepalese economic development. The paper is based on secondary data and literature reviews. Insurance can be acknowledged as tool that shares risk, offers financial protection, minimizes the financial distress and accelerates the pace of economic growth. Insurance encourages saving in the society and collects the scattered fund in term of premium and invest for maximization. Presently 40 insurance companies (19 life insurance, 20 non-life insurance and 1 reinsurance) are operating in Nepal providing diversified range of services. Recently agriculture insurance on crop and livestock sector and health insurance policy is being offered through many governmental and private insurance companies of Nepal. Insurance Board statistics of 2017 revealed total premium of 46.97 billion rupees and $2.03 \%$ contribution in total gross domestic product. We cannot deny the fact that insurance market of Nepal is witnessing major obstacles in terms of new product innovation, service issues related to consumers and time lapse of long-term policy. The study concludes that with little improvisation based on market research and consumer awareness can lead insurance companies $\mathcal{E}$ the concept to a peak level in Nepal.
\end{abstract}

Keywords: Insurance, shares risk, financial protection, financial distress, economic growth

\section{Introduction}

\section{Background}

Obviously, the world is surrounded by risks and uncertainties in the 21st century of modernization and globalization. Especially, in developing country like Nepal, safety and security are one of the key issues. "Insurance is a system of combining much loss exposure, with the cost of the losses being shared by all the participants" as defined by (Crane1980). Insurance is probably a device providing financial compensation to those who suffer from misfortune. In other words, it is the best means for security to human life and property from various risks (Shrestha, 2001). Insurance is a kind of investment, from which one gets return only when certain loss occurred from predetermined incidents (Singh, 2009). 'A wellperforming and financially sound life insurance industry benefits consumers, producers and stockholders (Bikker, 2012). Moreover, life insurance encourages savings in the society because 
insured is paid back a lump sum amount with some bonus if he/she alive at the end of the period. Life insurance companies offer a variety of products in order to provide the financial protection in two extreme situations either living too long or dying too young (NCAER, 2011). It provides financial security to individual, encourages for long term savings and provides fund for developmental activities. Nepalese insurance company doesn't have a long history. Modern insurance companies in Nepal began from 1947 A.D. Lack of awareness in people about the significance of different aspects of insurance resulted people suffering heavy losses during accidents. "Maal Chalani ra Bima Company" is the first insurance company in Nepal which later was renamed as "Nepal insurance and Transport Company" in 1959 and further as "Nepal Insurance Company Ltd". In 1968, the government of Nepal established "Rastriya Bima Sasthan" under the Company act. Beema Samiti (Insurance Board) is an autonomous body, established to develop, systemize, regularize and regulate the insurance business of Nepal under Insurance Act, 1992" (Insurance Board of Nepal). In private sector, first life insurance company was established in 1988. During, 25 years period (1988-2012), the number of private sector life insurance companies reached to eight. There has been considerable interest of researchers in banking and capital market sectors, but they have paid less attention in insurance sector. Insurance company collects funds as premium method in accordance to their nature and corporate objectives (Insurance Board of Nepal). Total assets of insurance till 2012 reached to Rs. 67.18 billion. Among 25 commercial insurance companies, 8 are life, 16 are non-life and 1 is both life and non-life insurers have sold more than 1.3 million policies and collected more than Rs. 19700 million of premium. The contribution of gross insurance fees income to GDP (at current prices) in FY 2010/11 stood at 1.31 percent and it has created employment opportunities for 103,000 people directly and indirectly (Economic Survey, 2011/12). Nepalese insurance industry is small in size and there is absence of Reinsurance Company and separate entity of microinsurance institution (IB, 2012).

In Nepalese economy, the economic significance of insurance sector is increasing since last decade. Financially sound and healthy insurance company can deliver its services to customers more effective way as compared to the financially weak company. Therefore, there is the equal concern of policyholders, shareholders, regulating authority, Government, and society about the performance of insurance companies. So, the study aims to study the product offered by different insurance companies of Nepal, to assess their contribution and efficiency in economic development of Nepal.

\section{Statement of Problems}

Nepalese insurance companies are the successful enterprises of Nepal, which are still running the insurance business without suffering any losses from the date of establishment until now. So not only national insurance companies, nowadays more international insurance companies are also operating to transact insurance business. Most of the companies are earning profit each year. However, it is not significant and satisfactory against the volume of transaction if we give an overlook in the balance sheet and profit and loss account. The volumes of transaction are increasing tremendously year by year, but the growth of net earning is not in the same 
ratio. It is because of private waiting under raining and cut-throat competition in the market. All the insurance companies of Nepal are earning less because of the following reasons:

- Lack of attractive collection schemes by providing discounts, and incentives to the policyholder for encourage paying premium in time.

- Negligence of agents, brokers and development officer for not helping to the company for premium collection despite receiving the insurance commission in huge amount.

- Negligence in evaluation of investment sector before investing fund.

- Time consuming procedure in accepting, issuing and dispatching policy. practice of only traditional insurances policies and schemes.

- Poverty is also main problem, the last reason is most of Nepalese people do not faith on insurance, and insurance companies are not taking interest to solve these kinds of problem.

\section{Objectives of the study}

The main objective is to find out the current situation of premium collection and investment position insurance companies. The specific objectives of this study are spelled out as:

- To review the types of insurance companies operating in Nepal and study product delivered.

- To examine the contribution of life insurance companies in economic development of Nepal on the reference of premium collection and investment pattern.

- To identify major problems facing by the insurance company and to evaluate the life insurance industry from policyholders' and experts' perspectives.

\section{Literature Review}

\section{Present status of insurance industry}

The history of insurance industry is not so long in Nepal. It has it root in the $20^{\text {th }}$ century. "Nepal Insurance and Transport Company Ltd" was established in 1947 A.D. Prior to these Indian insurer's branches were doing business in Nepal that was not regulated. Significant growth has been registered in the insurance industry of Nepal. The growth has been both quantitative and qualitative with increase in number of industry and range of services offered. Now altogether 40 insurance company among which 19 are life, 20 non-life and 1 reinsurance are operating in Nepal. The growth in the number of licensed industries from 1990 to 2019 is presented in Table 1.

\begin{tabular}{|c|c|c|c|c|c|c|c|c|c|c|}
\hline \multirow{3}{*}{$\begin{array}{c}\text { No. of Insurance } \\
\text { Companies }\end{array}$} & \multicolumn{9}{|c|}{ Year } & \multirow[b]{2}{*}{2019} \\
\hline & 1990 & 1995 & 2000 & 2005 & 2010 & 2011 & 2012 & 2013 & 2014 & \\
\hline & 5 & 9 & 11 & 19 & 25 & 25 & 25 & 25 & 26 & 40 \\
\hline
\end{tabular}

Table 1: Trends of Nepalese Insurance Industry Source: Strategic plan 2014-2019 (BEEMA SAMITI) 


\section{Types of insurance companies in Nepal}

All the insurance companies provided certainty against the risk that can be classified as life and general insurance. Life insurance may be defined as the certain sum of money either on the death of the insured or on the expiry of a fixed period and is concerned about physical and mental accident risk. Whereas, General insurance considers all insurance expect life insurance. When viewed from professional use insurance will take two board forms as life and non-life insurance. We can to see all the insurance under the view of risk point.

Table 2: Present status of Nepalese Insurance Companies

\begin{tabular}{|l|l|}
\hline Types of Insurance & Number \\
\hline Life Insurance & 19 \\
\hline Non-Life Insurance & 20 \\
\hline Re Insurance & 1 \\
\hline Total & 40 \\
\hline
\end{tabular}

Source: Insurance Board, 2019

\section{Life Insurance}

"Life insurance is a contract providing for payment of a sum of money to the person assured or to his nominee, on the happening of certain events" (Jyotsna \& Niswan 2007). Nepal Insurance Act 1992(section 2-1) has defined life insurance as "the contract of insurance, affected on human life on the basis of age to pay a fixed sum to the assured or his nominee, on the death or on the happening of any contingency, dependent on human life in consideration of payment of a fixed installment premium by the insured person".

Following insurance companies provide the life insurance service in Nepal.

1. Prime Life Insurance Company Ltd.

2. National life Insurance Company Ltd.

3. Nepal Life Insurance Company Ltd.

4. Life Insurance Corporation (Nepal) Ltd.

5. American Life Insurance

6. Met Life (ALICO)

7. Asian Life Insurance Company Ltd.

8. Surya Life Insurance Company Ltd.

9. Gurans Life Insurance Company Ltd.

10. IME Life Insurance Company Ltd.

11. Union Life Insurance Company Ltd.

12. Jyoti Life Insurance Company Ltd

13. Sun Nepal Lifw Insurance Company Ltd.

14. Reliance Life Insurance Company Ltd.

15. Reliable Life Insurance Company Ltd.

16. Citizen Life Insurance Company Ltd.

17. Sanima Life Insurance Company Ltd. 
18. Prabhu Life Insurance Company Ltd.

Insurance companies provides various polices in accordance to interest and desire of insured people. The policies in life insurance that are common in practice are as follows:

\section{Whole insurance:}

Whole insurance policy is a long-term policy that insures the individual throughout his life that helps in building the value that is paid out to beneficiary in case of death of policy holder. And the premium is fixed irrespective of the age. "Whole life insurance doesn't have any expiration date. When signing the contract, the insurance company and the policy holders agree to set a face value (amount of money benefit in case of death) and a premium" (Rull, Hong \& Victor 2004).

\section{Term insurance:}

Term insurance policy is beneficial for a short period of time and helps in immediate need. It protects a policyholder's life only until its expiration date. This policy premium is less than whole life insurance premium costs. Nepal has seen a steady increase in the expansion of branch insurance companies both in life and non-life insurance categories. As such, we can say that the upward trend in the insurance business is commendable. Life insurance companies have been going strong from 3 in 1990 to 35 in 2013 in the Capital, and with a massive increase in total branch numbers from 25 to a whopping 494 respectively as illustrated in figure 1 .

\section{Figure 1: Branches of Life Insurance Companies}

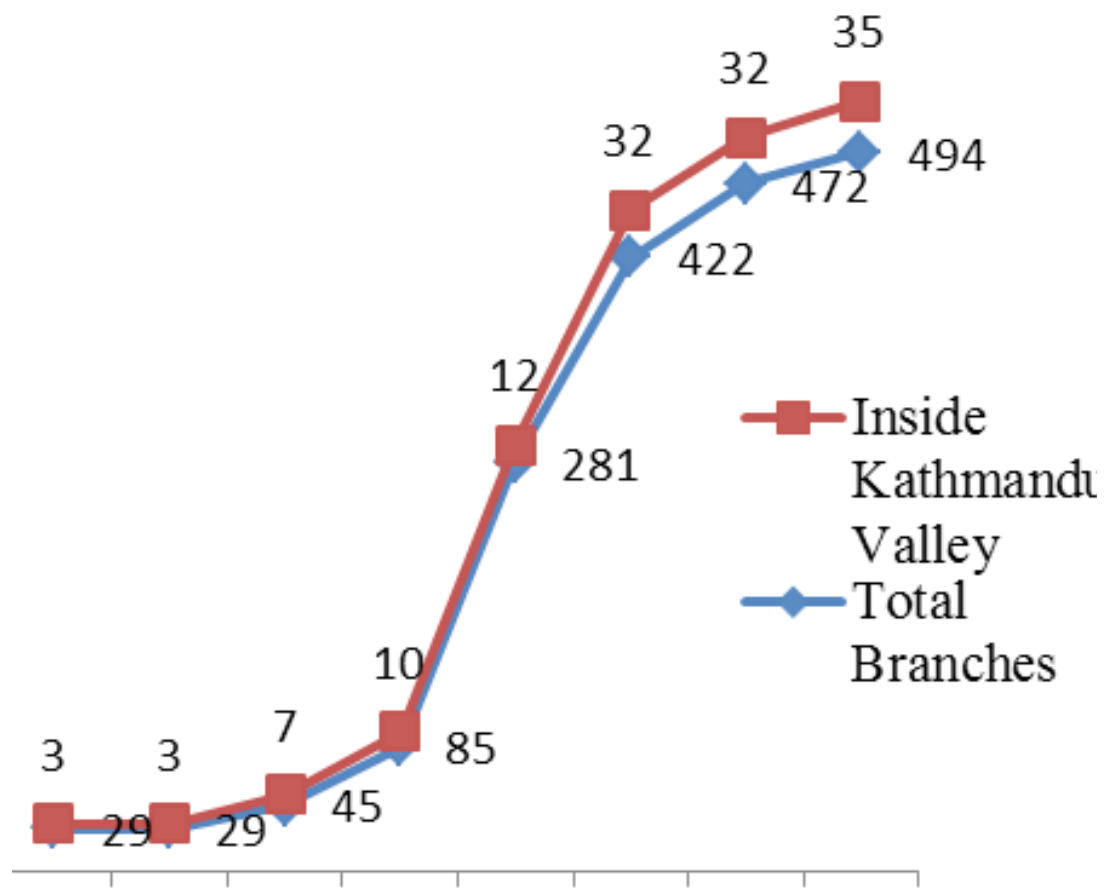


Source: Strategic plan 2014-2019 (BEEMA SAMITI)

\section{Non-Life Insurance}

Non-life insurance is also known as general insurance. It is a pure insurance because it can measure any risk in terms of money. In practice the insurers provide various types of non-life insurance policies, which are as follows.

\section{Fire Insurance}

Marine (Cargo) insurance

Aviation Insurance

Motor Insurance

Engineering Insurance

Money and Transit Insurance

Comprehensive Household Insurance

Burglary / Housebreaking Insurance

Fidelity Guarantee Insurance

Cash in Transit Insurance

Non-Life insurance companies have been going strong from 3 branches within the valley in 1990 to 43 in 2013 with a staggering total number of branches of 211 as illustrated in figure 2,

Figure 2: Branches of Non- Life Insurance Companies

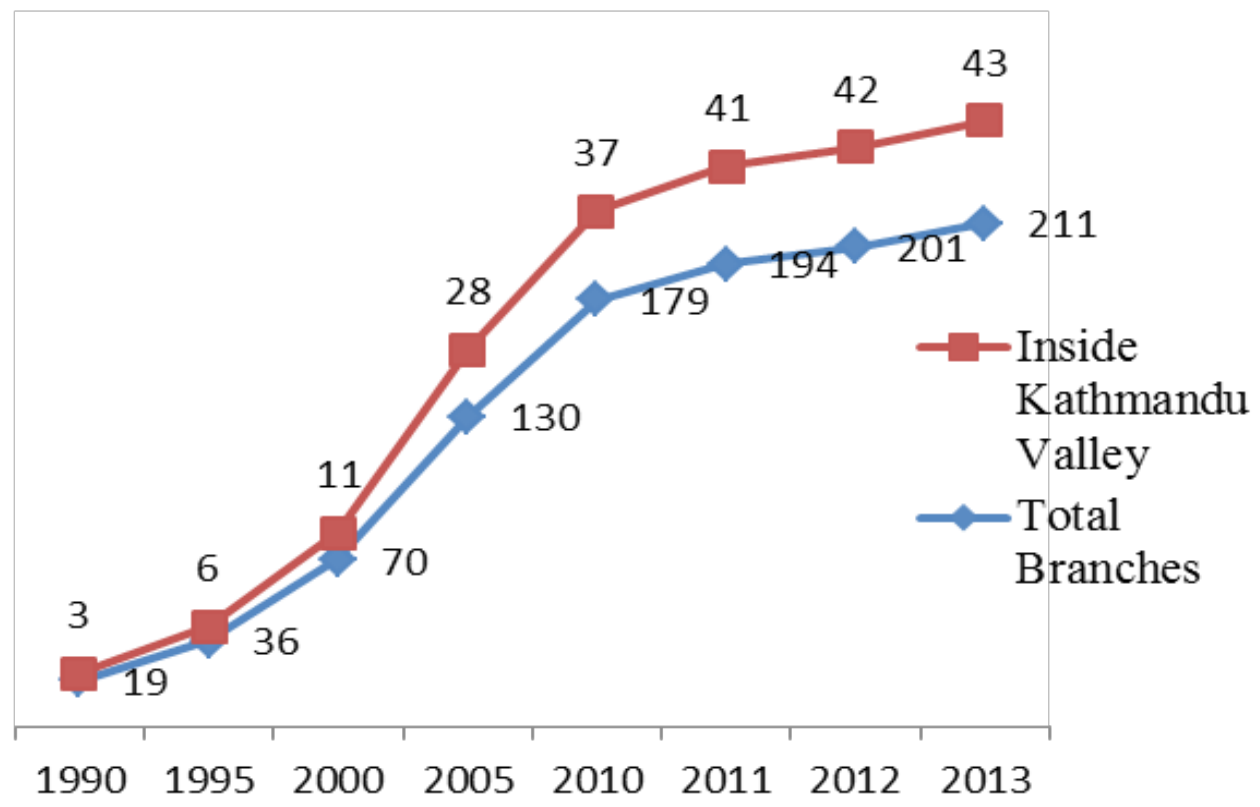

Source: Strategic plan 2014-2019 (BEEMA SAMITI)

Portfolio analysis of Life and Non-Life Insurance Companies 
Table 3: Major indicators of Life Insurance Companies (Assests, Liabilities, Premium and Claim - Rs. in million

\begin{tabular}{|l|r|r|r|r|r|r|r|r|}
\hline \multicolumn{10}{|c|}{ Year } \\
\hline \multirow{2}{*}{ Total Assets } & $\mathbf{1 9 9 0}$ & $\mathbf{1 9 9 5}$ & $\mathbf{2 0 0 0}$ & $\mathbf{2 0 0 5}$ & $\mathbf{2 0 1 0}$ & $\mathbf{2 0 1 1}$ & $\mathbf{2 0 1 2}$ & $\mathbf{2 0 1 3}$ \\
\cline { 2 - 10 } & 81.8 & 2500.34 & 7307.73 & 18099.44 & 45755.77 & 56992.43 & 69745.24 & 82271.72 \\
\hline $\begin{array}{l}\text { Total } \\
\text { Liabilities }\end{array}$ & 81.8 & 2500.34 & 7307.73 & 18099.44 & 45755.77 & 56992.43 & 69745.24 & 82271.72 \\
\hline $\begin{array}{l}\text { Total } \\
\text { Premium }\end{array}$ & 194.89 & 428.63 & 1075.12 & 3757.42 & 11010.03 & 12608.59 & 16040.96 & 18229.09 \\
\hline Total Claim & 20.08 & 40.29 & 68.44 & 202.91 & 1549.65 & 1910.48 & 3558.94 & 4418.11 \\
\hline $\begin{array}{l}\text { Number of } \\
\text { Policies (in } \\
\text { '000) }\end{array}$ & 31 & 54 & 96 & 381 & 1910 & 2175 & 2939 & 3556 \\
\hline $\begin{array}{l}\text { Number of } \\
\text { claims (in '000) }\end{array}$ & 2 & 7 & 15 & 22 & 45 & 53 & 64 & 77 \\
\hline
\end{tabular}

Table 4: Major indicators of Non-Life Insurance Companies (Assests, Liabilities, Premium and Claim)

(Rs in million)

\begin{tabular}{|c|c|c|c|c|c|c|c|c|}
\hline \multirow[b]{3}{*}{ Total Assets } & \multicolumn{8}{|c|}{ Year } \\
\hline & 1990 & 1995 & 2000 & 2005 & 2010 & 2011 & 2012 & 2013 \\
\hline & 783.55 & 1217.29 & 2716.88 & 5240.22 & 9685.85 & 11377.79 & 12957.99 & 14809.24 \\
\hline $\begin{array}{l}\text { Total } \\
\text { Liabilities }\end{array}$ & 783.55 & 1217.29 & 2716.88 & 5240.22 & 9685.85 & 11377.79 & 12957.99 & 14809.24 \\
\hline Total Premium & 106.4 & 336.63 & 1004.62 & 2262.1 & 6281.37 & 6653.91 & 7463.7 & 8784.3 \\
\hline Total Claim & 32.25 & 85.38 & 405.99 & 1252.54 & 2553.66 & 3654.86 & 4546.15 & 3172.57 \\
\hline $\begin{array}{l}\text { Number of } \\
\text { Policies (in '000) }\end{array}$ & 14 & 22 & 38 & 95 & 440 & 600 & 683 & 768 \\
\hline $\begin{array}{l}\text { Number of } \\
\text { claims (in '000) }\end{array}$ & 1 & 1 & 1 & 6 & 36 & 48 & 42 & 45 \\
\hline
\end{tabular}

Looking to the portfolio analysis of insurance companies, it reveals a promising outlook on the insurance market in Nepal. The total assets of life insurance companies have increased from NRs. 81.80 million to NRs. 82,271.72 million. Likewise, the total assets of non-life insurance companies have made a dramatic leap from NRs. 783.55 million to NRs. 14809.24 million. Liabilities on the other hand is showing similar trends although this can be said to be "part of business" since liabilities in the insurance business tends to be relatively high.

Premium has been showing a favorable outlook since 1990 with the initial of NRs. 194.89 in 1990 to NRs. 18,229.09 in 2013 for life insurance companies and initial of NRS. 106.40 to NRs. 8,784.30 in 2013 for non-life insurance companies respectively. Life insurance companies have distributed claims of NRs. 20.08 million in 1990 compared to a whopping NR. 4,418.11 in 2013 while total claim for non-life insurance companies increased from NRs. 32.25million in 1990 
compared to a whopping NR. 3,172.57 in 2013. Putting this in number, the total claim for non-life insurance companies in 1990 was only 1 thousand while the number of policies issues was 14 thousand. These increase up to 45 thousand and 768 thousand in 2013 respectively. Life insurance companies issued 31 thousand policies in 1990 and paid claim of 2 thousand that increased up to 3,556 thousand and 77 thousand in 2013 respectively. Thus, the above analysis suggests a positive outlook on the insurance business in Nepal which is experiencing a large increase in the middle-class population and an increased inflow of remittance along with an increased population of educated youths.

\section{Products offered by Nepalese Life and Non-Life Insurance}

These total 40 insurance companies of Nepal are providing range of insurance against different risk where a small amount of premium payment can offer a large amount of benefits. Risk covered by insurance companies as reported by Ghimire (2014) is as below:

Economic Risk: In advance economies different loss caused by business failure, unemployment and trade related risk can be managed or supported by insurance.

\begin{tabular}{|c|c|c|c|c|c|c|c|}
\hline \multirow[b]{2}{*}{ S.N } & \multirow[b]{2}{*}{ Description } & \multicolumn{5}{|c|}{ Year } & \multirow{2}{*}{$\begin{array}{c}\text { Estimation } \\
2020\end{array}$} \\
\hline & & 2013 & 2014 & 2015 & 2016 & 2017 & \\
\hline 1 & World & 3.3 & 3.4 & 3.1 & 3.2 & 3.5 & 3.9 \\
\hline 2 & $\begin{array}{l}\text { Developed } \\
\text { countries }\end{array}$ & 1.2 & 1.8 & 1.9 & 1.9 & 2 & 1.8 \\
\hline 3 & \begin{tabular}{|l|} 
Developing \\
Countries
\end{tabular} & 4.9 & 4.6 & 4 & 4.1 & 4.6 & 5.1 \\
\hline 4 & $\begin{array}{l}\text { Developing } \\
\text { Asian }\end{array}$ & 6.9 & 6.8 & 6.6 & 6.4 & 6.3 & 6.4 \\
\hline 5 & \begin{tabular}{|l|} 
European \\
Union Nation \\
\end{tabular} & 0.3 & 1.4 & 2 & 1.8 & 1.9 & 1.8 \\
\hline 6 & India & 6.6 & 7.2 & 7.3 & 7.5 & 7.5 & 7.8 \\
\hline 7 & Nepal & 4.1 & 5.4 & 3.4 & 0.5 & 4.5 & 3.8 \\
\hline
\end{tabular}

Social Risks: Different domestic and international crime, violence and riots related risk are insurable globally and in Nepal too. Commercial insurance companies sell their insurance policies against these risks.

Life risks: Life insurance policy provides financial protection against the premature death of bread earners of the family. Likewise, financial burden raised due to health-related problem from mild to chronic disease can be supported by different health insurance policies by government and private insurance companies. 
Environmental Risks: Insurance company provide financial protection against the environment related risk such as: pollution, deforestation, land degradation. Any loss happens due to such risk, insurers provide financial compensation to the policyholders.

Natural Risks: Loss caused by various natural disasters like Heavy rainfall, landslides, earthquakes, floods and drought is very high and is impossible to bear by single person or family and even the government. Insurance companies provide protection against such loss. Specially, farmers are suffering from such risks. Few insurance companies in Nepal had also launched agriculture insurance to protect crops and livestock.

\section{International and National Economy Situation}

The insurance market is dependent upon the economic situation of the country and world.

Table 5: Economic situation of the world

Source: Nepal Tourism Board, 2018

Despite of economic crisis for early $21^{\text {st }}$ century the world's economy is in good progress. As compared to Nepal Indian economic growth is at good pace. Nepalese economy growth is at the rate of 4.5 percent in 2017.

\section{Contribution of Total Insurance Premium to Country Gross Domestic Product}

Gross Domestic product (GDP) is a term to evaluate country's economic wellbeing (Nepal, 2012). Higher the GDP higher is the country economic prosperity. The total insurance Premium, Total GDP and Insurance contribution to GDP is as given in Table 6.

Table 6: Contribution of total insurance premium in GDP

\begin{tabular}{|c|c|r|r|r|r|r|}
\hline & & \multicolumn{5}{|c|}{ Year } \\
\cline { 3 - 7 } S.N & Description (in Billions) & \multicolumn{1}{|c|}{$\mathbf{2 0 1 3}$} & \multicolumn{1}{c|}{$\mathbf{2 0 1 4}$} & \multicolumn{1}{c|}{$\mathbf{2 0 1 5}$} & \multicolumn{1}{c|}{$\mathbf{2 0 1 6}$} & \multicolumn{1}{c|}{$\mathbf{2 0 1 7}$} \\
\hline $\mathbf{1}$ & Total Insurance Premium & 22.01 & 24.63 & 30.43 & 36.51 & 46.97 \\
\hline $\mathbf{2}$ & Total GDP & 1527.3 & 1675 & 1941.6 & 2124.6 & 2309.42 \\
\hline & Insurance contribution in & & & & & \\
$\mathbf{3}$ & GDP (\%) & 1.44 & 1.47 & 1.57 & 1.71 & 2.03 \\
\hline
\end{tabular}

Source: Nepal Tourism Board, 2018

In 2017 the total Insurance premium was 46.97 billion rupees while Total GDP was 2309.42 billion rupees. The contribution of insurance premium in GDP from 2013 to 2017 are $1.44 \%$, $1.47 \%, 1.57 \%, 1.71 \%$ and $2.03 \%$ respectively. This indicated that with the increase in insurance premium its contribution to Nepalese GDP is also increasing. 


\section{Review on past Literatures}

Thapa and Neupane (2056 BS) revealed that the insurance business started to flourish in Nepal because many industries were established, and the people really became aware of the businesses. As a result, many people were involved in it which ultimately contributed to the national development. They reported around 19 insurance companies working in Nepal.

Adhikari (2000) in his research work "A study on investment policies and practices" found what are the main policies used to invest the collecting premium of insurance industries and concluded major portion of investment was incepted within the head 'Government Securities' and 'Bank Fixed Deposit' of both life and non-life insurance industries.

In 2001 Shrestha, reported insurance companies collect the scattered savings of the people in the form of premium and then invest it in the form of capital on a long-term basis in development projects together with providing protection from various types of risks. Insurance companies stop the flow of capital outside the country. In this manner, insurance companies are playing a vital role in the country as far as the development of insurance business.

Shrestha (2002) published "A study on premium collection and investment position of National Life and General Insurance Company Limited". and recommended; insurance company must collect more first life insurance premium and issue new policy, they should diversify its life investment and increase investment in policy loans and they must establish research and development department and increase the efficiency of employees.

Likewise, Thapa (2002) also published "A comparative study on premium collection and investment pattern". With a aim to examine how far the different insurance premium are collected and invested them properly.

Similarly, Das, Davies and Podpiera (2003) proposed different financial soundness indicators to analyze the financial performance and risk profile of insurance companies. These indicators include; capital adequacy, management soundness, assets quality, reinsurance and actuarial issues, earnings and profitability, liquidity, and sensitivity to market risk which are categorized in core set and encouraged set. Core set serves the fundamental and encouraged set provides the important additional financial information about the insurance companies.

Beck and Webb (2003) claims that the life insurance market has become an increasingly prominent part of the financial sector over the past 40 years, providing a range of financial services for consumers and becoming a major source of investment in capital market.

Arena (2006) tested the causal relationship between insurance and economic growth using GMM for the dynamic model and found concrete evidence of positive and significant causal relationship between both life and non-life insurance and economic growth. 
Gelal (2006) published "A comparative financial analysis of Nepal Insurance Company and National Life and General Insurance Company Limited". He used mainly financial tools like ratio analysis, cash flow analysis to come in decision. After detailed study, Mr. Gelal concludes premium collection of both life and non-life insurance shows growing trend of insurance business in the recent year of the study period.

Likewise, an empirical analysis of interaction between financial development and economic growth concluded that there is a significant and positive relationship between economic growth and financial intermediary (Huang \& Lin, 2007).

Brainard (2008) contends that insurance contributes materially to economic development by improving the investment climate and promoting a more efficient mix of activities than would be undertaken in the absence of risk management instruments.

Darzi (2011) in his Doctoral dissertation entitled "Financial performance of insurance industry in post liberalization era in India" compare the financial performance of public and private sector general insurance companies for the period 2004/05 to 2008/09. The study concludes that the financial performance of insurers in post liberalization period is better than during the pre-liberalization period.

(Oke, 2012) find out the short and long-run relationship between economic growth and insurance sector development in Nigerian Economy by implying fixed-effect model and reveals that development of insurance sector positively and significantly affects economic growth

Similarly, Verma \& Bala (2013) examined the relationship between life insurance and economic growth using regression Model to analysis the data revealed that life insurance has both positive and significant impact on economic growth in India.

\section{Challenges of Insurance Industries in Nepal}

The development and growth of insurance sector in any country depends on economic development and economic prospects in the immediate future. Generally, there is a positive correlation between the economic development of a country and amount people spend on insurance. In addition, the demand for insurance is influenced by the general price level, price of insurance service, the aversion to risk and specific social and political features of a country. Insurance industries have been affected by many stakeholders like Government and ministries, insurance industry player, service provider, learning institute, media, Financial sector and regulators, policy holders and its staffs having positive or negative effect on the insurance industries. Nepalese insurance market is being constrained by various challenges. Majority of them includes low and irregular income, low level of insurance awareness, small market size, unhealthy competition, shortage of competent human resources, low risk of 
retention capacity of insurers, limited access to reinsurance market, weak legal and regulatory framework and other known human hurdles (Strategic Plan, 2014-2019).

As middle- and low-class family with low purchasing power dominates the Nepalese population insurer are facing problem with awareness of insurance among the clients. Global economic crisis, slow economic growth curve and political instability is also causing hinderance among the insurers. Likewise, high level of economic inflation is also a great concern for insurance market because inflation results in premium level being depreciated in real terms. The inadequate development of financial market and lack of opportunities for safe, liquid and diversified investment yields reasonable return inhibits development of competitive insurance service.

\section{Conclusion}

Insurance can be acknowledged as a tool for protection which undoubtedly proves that insurance is a very important savings and risk tool for citizen of any country. But analyzing insurance sector showed that it has yet to be outreach for the common people residing in Nepal. In Nepal the general population are not well educated and aware about benefit of insurance and also are middle class who have low power of investment and insurance of Nepal has to cope with these challenges. Moreover, due to political instability and conflict among people in the name of politics development pace of country is pushed far behind. So, majority of the population are denying the adoption of insurance policy. Nowadays different report shows increased statistics of insurance holder each year.

This paper has attempted to review the insurance sector of Nepal, their types, product offered and status of Insurance Market in Nepalese economy. During 2017, Nepalese insurance company recorded a premium of 47.97 Billion rupees and GDP contribution of $2.03 \%$. Despite of the fact that insurance companies are increasing and so as their policy holder, insurance sector is witnessing major obstacles in terms new product innovation, service issues related to costumers and lapsation of long- term policy. So, it can be concluded that insurance companies have strived good till now but with little improvisation based on market research can lead insurance companies \& the concept to a level of excellence in Nepal.

\section{Reference:}

Adhikari, Narendara Dev, (2000), Insurance Industry in Nepal, “A study on investment policies and practices", MasterDegree Thesis, T.U., Kathmandu.

Arena, M. (2006). “ Does Insurance Market Activity Promote Economic Growth? Country Study for Industrial and Developing Countries." World Bank Policy Research Working Paper No. 4098.

Beck, Y., \& Webb, I. (2003). Economic demographic, and institutional determinants of life insurance consumption across the countries. The World Bank Economic Review. 17, 51-88. 
BeemaSamiti (Insurance Regulatory Authority of Nepal) (2019). An Assessment of Reinsurance Practice and its Impact on Nepalese Insurance Industry. Government of Nepal.

Beema Samiti (2014). Strategic plan 2014-2019. Government of Nepal.

Bhatia,Niswan \& Sethi,Jyotsna. 2007, Elements of Banking and Insurance, New Delhi.

Bikker, J. A. (2012). Performance of the life insurance industry under pressure: efficiency, competition and consolidation. DNB Working Paper, 357. Netherlands.

Brainard, L. (2008). What is the role of insurance in economic development? Zurich Government and Industry Affairs.

Darzi, T. A. (2011). Financial performance of insurance industry in post liberalization era in India. Doctoral dissertation, University of Kashmir, Srinagar.

Das, U. S., Davies, N., \& Podpiera, R. (2003). Insurance and issues in financial soundness. IMF Working Paper no. 03/18. Washington D.C.: International Monetary Fund.F,Crane.1980, Insurance Principle and Practices, John Willey and Sons.

Gelal, Shree Prasad, (2006), "A comparative financial analysis of Nepal Insurance Company and National Life and General Insurance Company Limited", An unpublished Master Degree Thesis (S.D.C.), T.U., Kathmandu.

Ghimire, R. (2014). Insurance Industry and Economic Growth in Nepal : A Study with Granger Causality Test Approach. Social Science Research Network , 4 (2), 1-6.

Huang, H.C. and \& Lin, S.C. (2007). Joint Determination of Finance and Growth: An. 1-34 Insurance Act 1992, Nepal Government.

Insurance Board (2012). Annual Report, 2011/12. Kathmandu, Nepal.

Insurance Board (2012). Current Situation of Insurance Industry and Analysis of Trends. Kathmandu.

Insurance Board (2018), Annual Report, Government of Nepal.

Jay H.Hong, Jose-victor, 2004, Life Insurance And Household Consumption, FRB Philadelphia Working Paper No. 04-01.

NCAER (2011). Pre-launch report of insurance campaign. National Council of Applied Economic Research. New Delhi.

Nepal, R.K. (2012). The Insurance Market of Nepal. Arcada. Bachleor Thesis, International Business

Oke, M. O. (2012). Insurance sector development and economic growth in Nigeria. African Journal of Business Management , 6 (23), 7016-7023.

Shrestha, H. P. (2001). Business organization and office management. Kathmandu: Ratna Pustak Bhandar. 
Shrestha, Shaillendra, (2002), "A study on premium collection and investment position of National Life and General Insurance Company Limited", An unpublished Master Degree Thesis (S.D.C.), T.U., Kathmandu.

Singh, H. B. (2009). Banking and insurance (4th ed). Kathmandu: Asia Publications (P) Ltd.

Thapa, K., \& Neupane, K. D. (2056). Banking and insurance. Kathamandu: Asmita Books.

Thapa, Tara Bahadur, (2002), Insurace industry in Nepal; “A comparative study on premium collection and investment pattern", Master Degree Thesis T.U., Kathmandu.

Verma, A., \& Bala, R. (2013). The Relationship between Life Insurance and Economic Growth: Evidence from India. Global Journal of Management and Business Studies, 3 (4), 413422. 